\title{
Photosynthesis-irradiance relationships in microalgae associated with Antarctic pack ice: evidence for in situ activity
}

\author{
Michael P. Lizotte ${ }^{*}$, Cornelius W. Sullivan \\ Marine Biology Research Section, Department of Biological Sciences, University of Southern California, Los Angeles, \\ California 90089-0371, USA
}

\begin{abstract}
Microalgae associated with a broad range of pack ice microhabitats were examined for photosynthesis-irradiance characteristics in relation to light availability. Pack ice, the dominant form of sea ice in the southern ocean, was sampled from the Weddell-Scotia Sea and west of the Antarctic Peninsula during the austral autumn and winter as part of the Antarctic Marine Ecosystem Research at the Ice Edge Zone (AMERIEZ) project. Microalgae from pack ice exhibited lower photosynthetic capacity $\left(P_{\mathrm{m}}^{\mathrm{B}}\right)$ and $I_{k}$ values at (1) greater depths within profiles of annual ice and (2) lower predicted irradiance levels. Proportional relationships between photosynthetic characteristics and irradiance are interpreted to represent photoadaptation by microalgae following their incorporation into a vertically growing ice sheet; this interpretation provides the first evidence of in situ physiological activity of microalgae within pack ice. Relative to the fast ice microalgae previously studied, pack ice microalgae had higher $P_{\mathrm{m}}^{\mathrm{B}}$ and $I_{k}$ values, and inhabited microenvironments exposed to higher irradiances. Thus, we conclude that rates of primary production by pack ice microalgae could be much higher than previously estimated from studies in fast ice regions and that sea ice microalgae have the potential to make a significant contribution to the primary production of the southern ocean, particularly during the winter and early spring when maximal ice cover significantly reduces the productivity of phytoplankton.
\end{abstract}

\section{INTRODUCTION}

Sea ice has 2 opposing effects on primary production in polar seas: a negative influence on phytoplankton photosynthesis by limiting light availability to the under-ice water column (Smith 1987), and a positive influence on sea ice microalgae by providing a solid substrate and a relatively constant physicochemical and irradiance environment (Garrison et al. 1986). Microalgae are found within sea ice and on ice crystal surfaces in contact with the seawater. There are 2 general categories of sea ice which can be distinguished with regard to ice crystal structure and the microalgal communities present: fast ice and pack ice (Weeks \& Ackley 1982). Fast ice occurs adjacent to land or ice shelves and typically forms a continuous ice sheet of similar age and thickness. Pack ice occurs over pelagic waters, and is typically a discontinuous

\footnotetext{
- Present address: Biology Department, Montana State University, Bozeman, Montana 59717, USA
}

assemblage of ice types of various ages and thicknesses.

Most of the work on photosynthesis by sea ice microalgae in the Antarctic has been conducted on fast ice communities near land-based research stations (see Horner 1985a, Palmisano \& Sullivan 1985, and Garrison et al. 1986 for reviews), even though fast ice probably constitutes less than $10 \%$ of total ice cover in the southern ocean. Studies on fast ice populations have been useful in understanding photosynthesis and growth in microalgae from such extreme environments, but the few studies on microalgae from pack ice suggest they have different photosynthetic characteristics (Burkholder \& Mandelli 1965, Irwin 1990, Lizotte \& Sullivan unpubl.). Pack ice includes a greater diversity of microenvironments inhabited by microalgae; these microhabitats can have physicochemical conditions different from the bottom ice and platelet ice typically investigated in fast ice regions (Ackley et al. 1979, Clarke \& Ackley 1984). Moreover, the species composition of algal communities found in pack ice differs from 
that found in fast ice (Horner 1985b, Garrison et al, 1986, 1987).

Most studies of microalgae from the pack ice in the Antarctic have concentrated on measurements of biomass and microscopic identification of microalgae (Ackley et al. 1979, Garrison et al. 1983, Clarke \& Ackley 1984, Marra \& Boardman 1984, Garrison \& Buck 1985, Garrison et al. 1987). Few have included photosynthesis measurements of ice-associated microalgae. Burkholder \& Mandelli (1965) reported on the photosynthesis-irradiance relationships of those microalgae living within surface ponds on ice floes caused by infiltration of seawater. Recent studies have shown that algae capable of photosynthesis occur throughout Antarctic pack ice (Kottmeier \& Sullivan 1987, 1990, Lizotte \& Sullivan unpubl.). Little is known about the photosynthesis-irradiance characteristics of microalgae distributed throughout the matrix of pack ice, and consequently, jittie is known about the potential contribution from pack ice to the primary productivity of the contiguous pelagic ecosystem. Reasons for this include: the limited number of expeditions into pack ice regions; the complexity of pack ice with regard to the diversity of microenvironments; and the technical limitations of sampling and conducting experiments under conditions representative of in situ sea ice microenvironments.

Given these limitations, we attempted to answer several basic questions which would contribute to understanding the potential for primary production in pack ice: (1) Are pack ice algae photosynthetically competent? (2) Are pack ice algae physiologically similar to fast ice algae? (3) Are pack ice algae physiologically active in situ?

We have previously addressed the first question by measuring photosynthetic carbon fixation in algae released from ice by melting (Kottmeier \& Sullivan 1987, 1990, Lizotte \& Sullivan unpubl.), and herein we elaborate by showing that they are capable of responding photosynthetically to a range of irradiances. In another paper (Lizotte \& Sullivan unpubl.), we also report that biomass-specific rates of light-saturated photosynthesis in microalgae from pack ice were much greater than maximal values for microalgae from fast ice habitats, but were similar to maximal rates reported for Antarctic phytoplankton. In this paper, we directly compare the photosynthesis-irradiance characteristics of pack ice microalgae with those reported for other groups of polar microalgae. Finding an answer to the third question is more difficult. Assuming that only physiologically-active algae can make phenotypic adaptations to environmental conditions, we propose that pack ice microalgae are active in situ if they exhibit adaptations in photosynthesis-irradiance characteristics as a response to ambient irradiance in the sea ice microenvironment following their incorporation into a vertically growing ice sheet. Photoadaptation in pack ice microalgae was investigated by comparing populations from a broad range of pack ice microenvironments, including vertical profiles of ice floes.

This study represents the first extensive study of photosynthesis-irradiance characteristics in microalgae from Antarctic pack ice; we know of only the isolated examples reported by Burkholder \& Mandelli (1965) and our own laboratory (SooHoo et al. 1987a). This research was conducted as part of the AMERIEZ project (Antarctic Marine Ecosystem Research at the IceEdge Zone) during cruises to the Weddell and Scotia Seas in autumn 1986 and winter 1988. An additional opportunity for sampling occurred while participating in the WINCRUISE project off the west coast of the Antarctic Peninsula in winter 1987.

\section{METHODS AND MATERIALS}

Sampling. Sea ice samples were collected during 3 cruises south of South America (Table 1). During the austral autumn of 1986 (March), sampling was conducted as part of the AMERIEZ project (AM-86), working in the western Weddell Sea from the USCG Icebreaker 'Glacier' (Sullivan \& Ainley 1987). During the austral winter of 1987 (June-July), sampling was conducted as part of the WINCRUISE project (WC-87) off the west coast of the Antarctic Peninsula (Quetin \& Ross 1989). During the austral winter of 1988 (JulyAugust), sampling was conducted during the second leg of the AMERIEZ cruises (AM-88) to the northwest Weddell-Scotia Sea (Ainley \& Sullivan 1989). WC-87 and AM-88 cruises were made on the RV 'Polar Duke'.

Ice was collected at the sea surface from an inflatable boat (Zodiac). The types of pack ice collected ranged in age from freshly formed ice crystals (grease ice) to annual pack ice ca $2 \mathrm{~m}$ thick and 10 to $100 \mathrm{~m}$ in the longest horizontal dimension (Table 1). Grease ice was scooped directly off the surface of the ocean in a clean polypropylene bucket or polyethylene jar. Pieces of nilas (also known as new ice or gray ice) and pancake ice less than $10 \mathrm{~cm}$ thick were cut with an aluminium snow knife. Pancake ice and annual ice floes thicker than $10 \mathrm{~cm}$ were sampled with a CRREL ice auger ( $7 \mathrm{~cm}$ diameter core barrel), and cut into sections 15 to $35 \mathrm{~cm}$ in length. Annual ice floes were sampled by SCUBA divers for 'bottom' samples at Stn 29 of AM-86 and at Stn 550 of WC-87; sample depth was estimated from total floe thickness. Perimeter ice samples were sawed from the edges of annual ice floes ('PER' and ' $2 \mathrm{~L}$ ') and an iceberg ('IB'); depth in Table 1 is the depth below the sea surface. Other surface ice samples 
Table 1. Samples collected from pack ice in the Weddell-Scotia Sea during AMERIEZ (AM) cruises and west of the Antarctic Peninsula during the WINCRUISE (WC) cruise

\begin{tabular}{|c|c|c|c|c|c|c|}
\hline Cruise-Year & $\begin{array}{l}\text { Sample } \\
\text { name }\end{array}$ & Date & Station & $\begin{array}{l}\text { Position } \\
\text { (S:W) }\end{array}$ & $\begin{array}{l}\text { Depth } \\
\text { (cm) }\end{array}$ & $\begin{array}{c}\text { Snow cover } \\
\text { (cm) }\end{array}$ \\
\hline \multicolumn{7}{|l|}{ Grease ice } \\
\hline WC- 87 & $\mathrm{AZ}$ & $27 \mathrm{Mar}$ & 454 & $62^{\circ} 28^{\prime}: 62^{\circ} 37^{\prime}$ & $0-2$ & 0 \\
\hline AM-88 & $2 \mathrm{~S}$ & $12 \mathrm{Aug}$ & 645 & $59^{\circ} 32^{\prime}: 47^{\circ} 44^{\prime}$ & $0-2$ & 0 \\
\hline \multicolumn{7}{|l|}{ Pancake ice } \\
\hline AM-86 & PAN & $25 \mathrm{Mar}$ & 23 & $65^{\circ} 44^{\prime}: 50^{\circ} 3^{\prime}$ & $0-5$ & 0 \\
\hline WC -87 & $\mathrm{~K}$ & 16 Jun & 309 & $63^{\circ} 8^{\prime}: 61^{\circ} 11^{\prime}$ & $0-6$ & 0 \\
\hline \multicolumn{7}{|l|}{ Nilas } \\
\hline WC -87 & 595 & $9 \mathrm{Jul}$ & 595 & $64^{\circ} 46^{\prime}: 65^{\circ} 56^{\prime}$ & $0-20$ & 0 \\
\hline WC-87 & 661 & $10 \mathrm{Jul}$ & 661 & $64^{\circ} 53^{\prime}: 64^{\circ} 34^{\prime}$ & $0-20$ & 0 \\
\hline AM-88 & $2 \mathrm{R}$ & 12 Aug & 645 & $59^{\circ} 32^{\prime}: 47^{\circ} 44^{\prime}$ & $0-20$ & 0 \\
\hline \multicolumn{7}{|l|}{ Pore water } \\
\hline AM-86 & $\mathrm{H}$ & $17 \mathrm{Mar}$ & 16 & $65^{\circ} 35^{\circ}: 48^{\circ} 51^{\prime}$ & $9-29$ & 40 \\
\hline AM-86 & I & $19 \mathrm{Mar}$ & 18 & $65^{\circ} 24^{\circ}: 49^{\circ} 9^{\prime}$ & $31-41$ & 20 \\
\hline WC- 87 & Z & 19 Jun & 359 & $62^{\circ} 59^{\prime}: 62^{\circ} 17^{\prime}$ & $15-20$ & 29 \\
\hline \multicolumn{7}{|l|}{ Annual ice floes } \\
\hline AM-86 & BAND & $27 \mathrm{Mar}$ & 29 & $64^{\circ} 51^{\prime}: 50^{\circ} 42^{\prime}$ & $15-20$ & 20 \\
\hline AM-86 & BOTTOM & $27 \mathrm{Mar}$ & 29 & $64^{\circ} 51^{\prime}: 50^{\circ} 42^{\prime}$ & $140-150$ & 20 \\
\hline WC- -87 & C & $15 \mathrm{Jun}$ & 304 & $63^{\circ} 43^{\prime}: 61^{\circ} 7^{\prime}$ & $75-90$ & 0 \\
\hline WC -87 & BOTTOM & $1 \mathrm{Jul}$ & 550 & $64^{\circ} 24^{\prime}: 63^{\circ} 17^{\prime}$ & $50-60$ & 22 \\
\hline \multirow[t]{5}{*}{ AM-88 } & $2 K-1$ & 4 Aug & 529 & $59^{\circ} 28^{\prime}: 44^{\circ} 0^{\prime}$ & $0-20$ & 33 \\
\hline & $2 \mathrm{~K}-2$ & & & & $20-40$ & \\
\hline & $2 \mathrm{~K}-3$ & & & & $40-60$ & \\
\hline & $2 \mathrm{~K}-4$ & & & & $60-82$ & \\
\hline & $2 \mathrm{~K}-5$ & & & & $82-109$ & \\
\hline \multirow[t]{5}{*}{ AM-88 } & $2 V-1$ & $12 \mathrm{Aug}$ & 645 & $59^{\circ} 32^{\prime}: 47^{\circ} 44^{\prime}$ & $0-29$ & 0 \\
\hline & $2 V-2$ & & & & $29-49$ & \\
\hline & $2 V-3$ & & & & $49-80$ & \\
\hline & $2 V-4$ & & & & $80-111$ & \\
\hline & $2 V-5$ & & & & $111-146$ & \\
\hline \multicolumn{7}{|c|}{ Perimeter and surface ice } \\
\hline AM- 86 & IB & 17 Mar & 16 & $65^{\circ} 35^{\circ}: 48^{\circ} 50^{\prime}$ & $0-10$ & 0 \\
\hline AM-86 & PER & $19 \mathrm{Mar}$ & 18 & $65^{\circ} 24^{\circ}: 49^{\circ} 9^{\prime}$ & $0-10$ & 0 \\
\hline WC- 87 & EPPS & 24 Jun & 396 & $63^{\circ} 4^{\prime}: 62^{\circ} 24^{\prime}$ & $0-50$ & 0 \\
\hline AM- 88 & $2 \mathrm{~L}$ & 4 Aug & 529 & $59^{\circ} 24^{\prime}: 43^{\circ} 59^{\prime}$ & $0-20$ & 0 \\
\hline AM-88 & $2 Q$ & $12 \mathrm{Aug}$ & 645 & $59^{\circ} 32^{\prime}: 47^{\circ} 44^{\prime}$ & $0-50$ & 0 \\
\hline
\end{tabular}

('EPPS' and '2Q') were small pieces of colored ice presumably broken off annual (or multi-year) ice floes; depth in Table 1 is the approximate diameter. 'Pore water' samples were hand-pumped from interstitial space within annual ice floes, which occurred at a depth approximately level with the freeboard of the floe.

Ice samples were placed in separate polyethylene jars and stored in a dark insulated chest until returned to the ship. A measured volume of filtered $(0.2 \mu \mathrm{m}$ pore size) seawater (FSW) was added within $1 \mathrm{~h}$ of collection, and the ice was allowed to melt in the dark at $0^{\circ} \mathrm{C}$. All analyses were begun within $12 \mathrm{~h}$ of collection; this dark period was shorter than the local night experienced by these microalgae in situ, and presumably did not affect their relative photoadaptive state. More FSW was added, if necessary, to maintain salinity between 29 and 35 ppt (measured with a refractometer) for reducing osmotic stress to the microalgae. The initial volume of ice was calculated from the difference between the final volume and the volume of FSW added. 'Pore water' samples were not diluted because they had salinities approximately equal to local seawater ( 33 to $35 \mathrm{ppt}$ ).

Chlorophyll concentration. Subsamples of ice microalgae were concentrated on Whatman GF/C filters and stored at $-20^{\circ} \mathrm{C}$. Filtered material was extracted in $90 \%$ acetone for 8 to $12 \mathrm{~h}$ at $4{ }^{\circ} \mathrm{C}$ in the dark. Chlorophyll a (chl a) concentration in the extract was determined with a Turner Designs model 10 fluorometer calibrated with standard amounts of purified chl a (Sigma Chemical Co.), and corrected for phaeopigment fluorescence (Holm-Hansen et al. 1965).

Photosynthesis-irradiance experiments. Measurements of photosynthesis as a function of irradiance (P-I) were made using a modification of the short-term, 
small-volume incubation method of Lewis \& Smith (1983). A subsample of the microalgal suspension was inoculated with a solution of $\mathrm{NaH}^{14} \mathrm{CO}_{3}$ (ICN Pharmaceuticals, Inc.) to produce a final activity of 1 to $3 \mu \mathrm{Ci}$ $\mathrm{ml}^{-1}$. Replicate aliquots (5 to $20 \mathrm{ml}$ ) were dispensed into 20 to 27 acid-rinsed glass scintillation vials. The contents of 3 vials were each immediately filtered through separate Whatman GF/C filters, rinsed 3 times with FSW, and frozen at $-20^{\circ} \mathrm{C}_{i}$ these samples constituted a control for residual background radioactivity which was subsequently subtracted from all ${ }^{14} \mathrm{C}$ uptake values. The remaining vials were incubated for 2.0 to $4.3 \mathrm{~h}$ at $-1.9^{\circ} \mathrm{C}$ over a range of irradiances ( 1 to $372 \mu \mathrm{E}$ $\mathrm{m}^{-2} \mathrm{~s}^{-1}$ ) produced by a $500 \mathrm{~W}$ tungsten halogen lamp attenuated with neutral density screens; irradiances were measured with a Biospherical Instruments $4 \pi$ steradian scalar irradiance meter. Triplicate $0.1 \mathrm{ml}$ aliquots were placed in scintillation vials to determine the concentration of radioisotope in each experiment; 0.1 $\mathrm{ml}$ of $1 \mathrm{~N} \mathrm{NaOH}$ was added to prevent loss of ${ }^{14} \mathrm{CO}_{2}$ upon addition of scintillation cocktail. Incubations were ended by turning off the light source in a darkened room; within $10 \mathrm{~min}$, all samples were filtered through separate Whatman $\mathrm{GF} / \mathrm{C}$ filters, rinsed 3 times with FSW, and frozen at $-20^{\circ} \mathrm{C}$. All filters were later thawed and fumed for $15 \mathrm{~s}$ over concentrated $\mathrm{HCl}$ and dried at $60^{\circ} \mathrm{C}$ to remove residual inorganic ${ }^{14} \mathrm{C}$. Radioactivity was determined by liquid scintillation counting on an LKB model 1210 or Beckman model LS3801 scintillation counter on board ship, and counts per minute were corrected to disintegrations per minute based on sample quench detected by the external standards ratio.

Rates of carbon fixation were calculated as in Strickland \& Parsons (1972) assuming the total dissolved inorganic carbon concentration was at a level typical for seawater, $25 \mathrm{mg} \mathrm{l}^{-1}$. Data were normalized to chl a and fitted, utilizing Marquadt's algorithm, to a hyperbolic tangent function (Jassby \& Platt 1976) with a respiration term:

$$
P^{\mathrm{B}}=P_{\mathrm{m}}^{\mathrm{B}} \tanh \left(I \frac{\alpha}{p_{\mathrm{m}}^{\mathrm{B}}}\right)+R
$$

where $P^{\mathrm{B}}=$ biomass-specific photosynthetic rate; $I=$ irradiance; $\alpha=$ initial linear slope of the curve; $P_{\mathrm{m}}^{\mathrm{B}}=$ maximum biomass-specific photosynthetic rate i $_{i}$ and $R=$ respiration. In our experiments, the respiration term probably does not reflect any metabolic activity, but was included to prevent including the origin when solving for the curve that gives the best fit to the data; this helps to correct for any errors associated with estimating background radioactivity. The range of irradiances used was inadequate for determining photoinhibition.

The conditions of salinity, temperature, and light under which we sampled and tested the pack ice microalgae were probably sufficient to conserve their physiological characteristics, as verified in other studies of P-I characteristics in sea ice microalgae (Bates \& Cota 1986, Palmisano et al. 1987). Furthermore, we observed microscopically that diatom cells were cytologically intact and that some pennate diatoms were motile following release from pack ice. Assuming our handling procedures did not adversely affect the pack ice microalgae, our results should be representative of their physiological state, and possibly of P-I characteristics in situ.

Irradiance. Surface downwelling irradiance in the range from 400 to $700 \mathrm{~nm}$, called photosynthetically available radiation (PAR), was recorded continuously during cruises using a hemispherical irradiance sensor (Biospherical Instruments, model QSR-240) interfaced to a digital integrator with output to a chart recorder. We quantified several characteristics of the ambient light field for each day: photoperiod, total PAR, maximum PAR, and mean PAR. Photoperiod and the maximum PAR value (typically near local noon) were estimated directly from each daily chart recording. Total PAR is the integrated irradiance for each day: for AM86, chart recordings were digitized at $1 \mathrm{~min}$ intervals and integrated, while for WC-87 and AM-88, total PAR was recorded from the digital integrator at the end of each day. Mean PAR is total PAR divided by photoperiod of each day.

We made a first-order approximation of irradiance within sea ice by adapting Beer's Law,

$$
I_{z}=I_{0} \mathrm{e}^{-k z}
$$

(where $I_{z}=$ irradiance at depth $z_{;} I_{0}=$ incident irradiance; and $k=$ extinction coefficient of the absorbing material) based on our data for incident irradiance and sample depth. Relative to the large variations we observed for $I_{0}$ and $z$ (over 2 orders of magnitude), $k$ approximates a constant for sea ice; the average bulk extinction coefficient for sea ice appears to be ca $1.5 \mathrm{~m}^{-1}$ (Maykut 1985). Therefore, we simplified Eq. (2) to:

$$
I_{z}=I_{0} \mathrm{e}^{-1.5 z}
$$

By introducing a simple correction for the loss of incident irradiance due to albedo $(A)$ for snow-covered sea ice (0.8) or bare sea ice (0.5) (Maykut 1985), we predicted the scale of in situ irradiance $\left(I_{z}^{*}\right)$ from incident irradiance corrected for depth and the presence of snow cover

$$
I_{z}^{*}=(1-A) I_{0} \mathrm{e}^{-1.5 z}
$$

We understand that $I_{z}$ and $I_{z}^{*}$ are not accurate models of in situ irradiance because they depend on simplified interpretations of extinction and albedo, and do not 
account for variations in the reflection, absorption, and scattering characteristics in ice and snow of different physicochemical composition (Maykut 1985). We based our scales of in situ irradiance on maximum PAR or mean PAR; therefore, we do not account for diel variation in incident irradiance or solar zenith angle. However, our purpose was to normalize the highly variable incident irradiance (between days, seasons, and locations) for the most obvious factors that affect irradiance in the ice column in order to test whether P-I characteristics in pack ice microalgae varied with available irradiance.

\section{RESULTS}

Microalgae from pack ice communities had photosynthesis-irradiance responses showing typical saturation curves (see Fig. 1 for examples). Maximal photosynthetic rates $\left(P_{\mathrm{m}}^{\mathrm{B}}\right)$ ranged from 0.09 to $4.57 \mu \mathrm{g} \mathrm{C} \mu \mathrm{g}$ chl $a^{-1} h^{-1}$, photosynthetic efficiency $(\alpha)$ ranged from

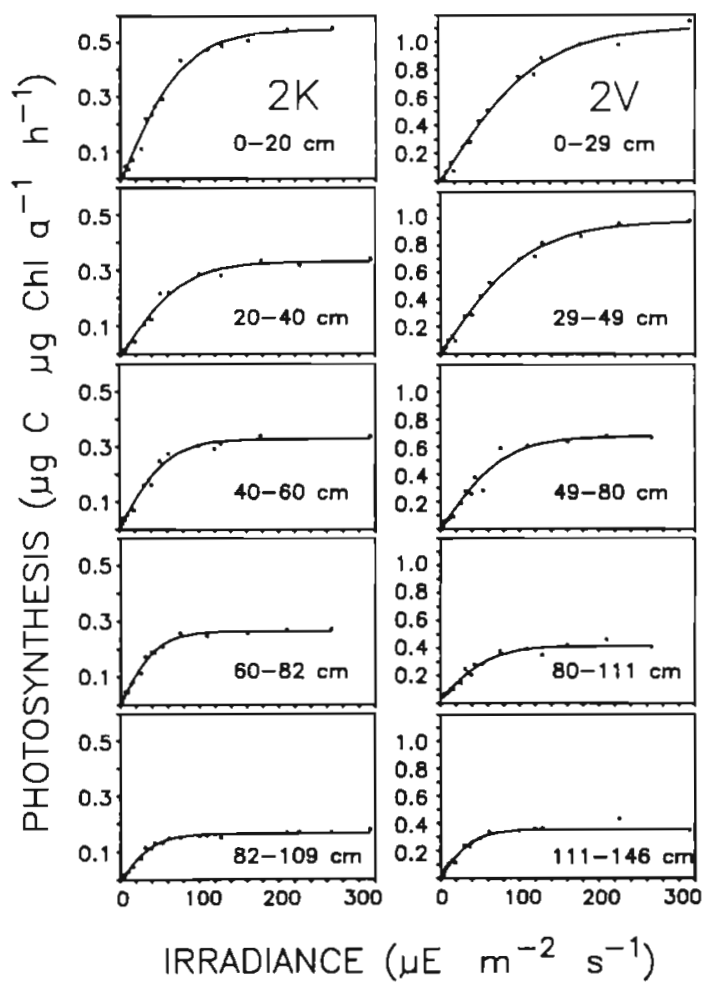

Fig. 1. Photosynthesis-irradiance curves for contiguous sections of cores from separate annual ice floes in the WeddellScotia Sea during August 1988

0.0036 to $0.058 \mu \mathrm{gC} \mu \mathrm{g} \mathrm{chl} a^{-1} \mathrm{~h}^{-1}\left(\mu \mathrm{E} \mathrm{m}^{-2} \mathrm{~s}^{-1}\right)^{-1}$, and the ratio of $P_{\mathrm{m}}^{\mathrm{B}}$ and $\alpha\left(I_{k}\right)$ ranged from 14 to $144 \mu \mathrm{E} \mathrm{m} \mathrm{m}^{-2}$ $\mathrm{s}^{-1}$ (Table 2). The highest $P_{\mathrm{m}}^{\mathrm{B}}$ and $\alpha$ values were found in perimeter and surface ice, and pancake ice, while the lowest values were found in cores of annual floes. The $R$ term of Eq. (1) ranged from -0.09 to $0.08 \mu \mathrm{g} \mathrm{C}$ ug chl $a^{-1} \mathrm{~h}^{-1}$, or from -3.5 to $17 \%$ when normalized to $P_{\mathrm{m}}^{\mathrm{B}}$ and did not appear to be significantly different from the origin. Low or insignificant values for $R$ are expected for short-term incubations with ${ }^{14} \mathrm{C}$, and in this case were probably errors associated with estimating background radioactivity

Microalgae from different sections of vertical cores of annual floes showed definite trends in P-I characteristics with depth (Fig. 1, Table 2). The 2 floes sampled ( $2 \mathrm{~K}$ and $2 \mathrm{~V}$ ) were located $213 \mathrm{~km}$ apart, were of different thickness, and differed in the amount and distribution of chl a with depth, suggesting they had different histories of formation. Therefore, we assume that similar trends in the P-I characteristics of the microalgae describe common adaptations to the physicochemical conditions (particularly irradiance) found at a certain depth in the ice column. Similar profiles were observed for P-I parameters in both floes, with $P_{\mathrm{m}}^{\mathrm{B}}$ and $I_{k}$ decreasing with depth; $\alpha$ did not show a consistent trend with depth.

Overall, relationships between the P-I characteristics of microalgae and the sample depth are more difficult to discern (Fig. 2). The highest values for $I_{k}, P_{\mathrm{m}}^{\mathrm{B}}$ and $\alpha$ were found in the surface populations, but low values were found at all depths. At best, these scatter plots may define upper limits dependent on depth.

Irradiance in pack ice is also a function of incident downwelling irradiance and photoperiod, which differed between cruises (Fig. 3) depending on the time of year, latitude, and local weather. The autumn cruise, AM-86, was the most southerly, but during March we experienced the longest photoperiod and the highest irradiance values. Autumn photoperiod was approximately double that observed during the winter cruises. We experienced the lowest values for photoperiod and irradiance during WC-87; this was the more southerly of the winter cruises, and PAR was further diminished by nearly constant overcast conditions and fog. The range of incident irradiance values included in our data set approaches or exceeds 2 orders of magnitude: total PAR ranged from 0.3 to $35 \mathrm{E} \mathrm{m}^{-2} \mathrm{~d}^{-1}$; mean PAR (total PAR divided by photoperiod) ranged from 15 to $770 \mu \mathrm{E}$ $\mathrm{m}^{-2} \mathrm{~s}^{-1}$; and maximum PAR ranged from 40 to $2700 \mu \mathrm{E}$ $\mathrm{m}^{-2} \mathrm{~s}^{-1}$. Most of the variation in incident irradiance during a particular cruise was due to local weather conditions, rather than seasonal variation or changing latitude.

P-I characteristics of pack ice microalgae showed positive correlations (Table 3, Fig. 4) to first-order approximations for scaling in situ irradiance by correcting incident PAR for depth $\left(I_{z}\right.$ Eq. 3) and for the influence of albedo ( $I_{z}^{*}$, Eq. 4). Correlations were made for linear regressions of $I_{\mathrm{k}}, P_{\mathrm{m}}^{\mathrm{B}}$ and $\alpha$ as a function of the scale of in situ irradiance based on maximum PAR or mean PAR for the appropriate sampling date. For $I_{z}^{*}$, 
Table 2. Chlorophyll a concentrations and photosynthesis-irradiance characteristics of microalgae collected from Antarctic pack ice. Standard deviations are given in parentheses. Units: chlorophyl a (chl a), $\mu \mathrm{g} \mathrm{l}^{-1} ; \alpha, \mu \mathrm{g} \mathrm{C} \mu \mathrm{g} \mathrm{chl} a^{-1}\left[\mu \mathrm{E} \mathrm{m} \mathrm{m}^{-2} \mathrm{~s}^{-1}\right]^{-1} ; P_{\mathrm{m}}^{\mathrm{B}} \mu \mathrm{g} C \mu \mathrm{g}$ chl $a^{-1} \mathrm{~h}^{-1} ; I_{k}, \mu \mathrm{E} \mathrm{m} \mathrm{m}^{-2} \mathrm{~s}^{-1}$

\begin{tabular}{|c|c|c|c|c|c|}
\hline Cruise-Year & $\begin{array}{c}\text { Sample } \\
\text { name }\end{array}$ & Chl a & $\alpha$ & $P_{\mathrm{m}}^{\mathrm{B}}$ & $I_{k}$ \\
\hline \multicolumn{6}{|l|}{ Grease ice } \\
\hline WC- 87 & $\mathrm{AZ}$ & 4.8 & $0.017(0.001)$ & $1.05(0.04)$ & 63 \\
\hline AM-88 & $2 \mathrm{~S}$ & 3.2 & $0.012(0.001)$ & $1.30(0.07)$ & 105 \\
\hline \multicolumn{6}{|l|}{ Pancake ice } \\
\hline AM-86 & PAN & 0.8 & $0.025(0.003)$ & $2.46(0.12)$ & 98 \\
\hline WC -87 & $\mathrm{~K}$ & 2.4 & $0.037(0.004)$ & $2.16(0.10)$ & 58 \\
\hline \multicolumn{6}{|l|}{ Nilas } \\
\hline WC -87 & 595 & 2.4 & $0.013(0.001)$ & $0.55(0.02)$ & 42 \\
\hline WC-87 & 661 & 1.8 & $0.025(0.002)$ & $0.81(0.03)$ & 32 \\
\hline AM-88 & $2 \mathrm{R}$ & 1.6 & $0.0068(0.0006)$ & $0.91(0.05)$ & 134 \\
\hline \multicolumn{6}{|l|}{ Pore water } \\
\hline AM-86 & $\mathrm{H}$ & 0.8 & $0.011(0.004)$ & $0.29(0.05)$ & 27 \\
\hline AM-86 & $\mathrm{I}$ & 0.6 & $0.015(0.004)$ & $0.82(0.07)$ & 53 \\
\hline WC-87 & Z & 2.6 & $0.0036(0.0005)$ & $0.12(0.01)$ & 34 \\
\hline \multicolumn{6}{|l|}{ Annual ice floes } \\
\hline AM-86 & BAND & 33.4 & $0.030(0.004)$ & $1.20(0.06)$ & 40 \\
\hline AM-86 & BOTTOM & 52.8 & $0.018(0.004)$ & $0.57(0.05)$ & 31 \\
\hline WC -87 & C & 14.2 & $0.0065(0.0012)$ & $0.091(0.007)$ & 14 \\
\hline WC-87 & BOTTOM & 540 & $0.026(0.003)$ & $0.76(0.04)$ & 29 \\
\hline \multirow[t]{5}{*}{$A M-88$} & $2 \mathrm{~K}-1$ & 4.3 & $0.0070(0.0005)$ & $0.57(0.02)$ & 81 \\
\hline & $2 \mathrm{~K}-2$ & 14.2 & $0.0044(0.0003)$ & $0.35(0.01)$ & 79 \\
\hline & $2 \mathrm{~K}-3$ & 17.0 & $0.0055(0.0005)$ & $0.33(0.01)$ & 60 \\
\hline & $2 \mathrm{~K}-4$ & 34.3 & $0.0057(0.0004)$ & $0.27(0.01)$ & 47 \\
\hline & $2 \mathrm{~K}-5$ & 55.2 & $0.0039(0.0003)$ & $0.17(0.01)$ & 44 \\
\hline \multirow[t]{5}{*}{ AM-88 } & $2 \mathrm{~V}-1$ & 8.4 & $0.0091(0.0005)$ & $1.15(0.03)$ & 126 \\
\hline & $2 V-2$ & 7.9 & $0.0088(0.0005)$ & $0.99(0.02)$ & 112 \\
\hline & $2 V-3$ & 7.0 & $0.0086(0.0010)$ & $0.69(0.04)$ & 81 \\
\hline & $2 V-4$ & 5.7 & $0.0063(0.0009)$ & $0.40(0.02)$ & 63 \\
\hline & $2 V-5$ & 5.5 & $0.0082(0.0007)$ & $0.35(0.01)$ & 43 \\
\hline \multicolumn{6}{|c|}{ Perimeter and surface ice } \\
\hline$A M-86$ & $\mathrm{IB}$ & 19.3 & $0.033(0.003)$ & $2.33(0.08)$ & 71 \\
\hline AM-86 & PER & 74.3 & $0.058(0.007)$ & $3.29(0.14)$ & 57 \\
\hline WC -87 & EPPS & 42.7 & $0.027(0.002)$ & $1.40(0.04)$ & 51 \\
\hline AM-88 & $2 \mathrm{~L}$ & 83.5 & $0.0055(0.0008)$ & $0.68(0.05)$ & 124 \\
\hline AM-88 & $2 Q$ & 30.4 & $0.032(0.002)$ & $4.57(0.17)$ & 144 \\
\hline
\end{tabular}

both $I_{k}$ and $P_{\mathrm{m}}^{\mathrm{B}}$ showed significant $(\mathrm{p}<0.01)$ positive correlations with in situ irradiance derived from either maximum PAR or mean PAR (Table 3); plots of $I_{k}, P_{\mathrm{m}}^{\mathrm{B}}$ and $\alpha$ as a function of mean $I_{z}^{*}$ are presented in Fig. 4. For $I_{z}$, the only significant correlation was with $I_{k}$, and only when $I_{z}$ was derived from maximum PAR $\left(\mathrm{r}^{2}=\right.$ $0.415, n=29, p<0.001)$. These correlations were not improved by additional changes to our scales for in situ irradiance based on further refinements of albedo for thin ice (grease, nilas, or pancake), or based on light attenuation by the pigments of overlying algal communities.

\section{DISCUSSION}

Microalgae removed from pack ice showed P-I responses typical of photosynthetic organisms and with rates as high as those reported elsewhere for polar microalgae (e.g. Burkholder \& Mandelli 1965, Platt et al. 1982, Palmisano et al. 1985, Irwin 1990). This suggests that cells released from ice by melting at 0 to $2^{\circ} \mathrm{C}$ into seawater either retained photosynthetic capacity in resting stages, or were vegetatively growing in situ. To test the possibility that microalgae are physiologically active within pack ice, we examined the photosynthetic characteristics of microalgae from vertical profiles and a broad range of light regimes that exist in different types of pack ice. Photoadaptation to the vertical gradient in irradiance known to exist through sea ice profiles (SooHoo et al. 1987b) or over a broad range of irradiance levels would provide evidence that vertically stable communities of microalgae were metabolically active within pack ice microenvironments.

Photoadaptation was indicated by consistent and 


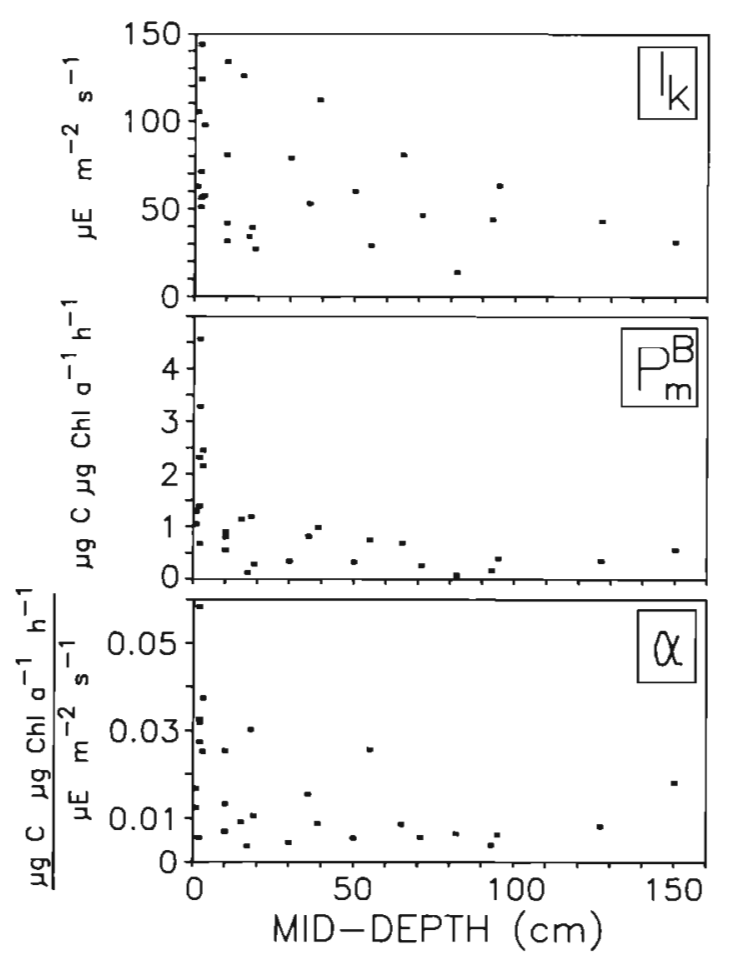

Fig. 2. Photosynthesis-irradiance characteristics in microalgae from Antarctic pack ice as a function of ice depth
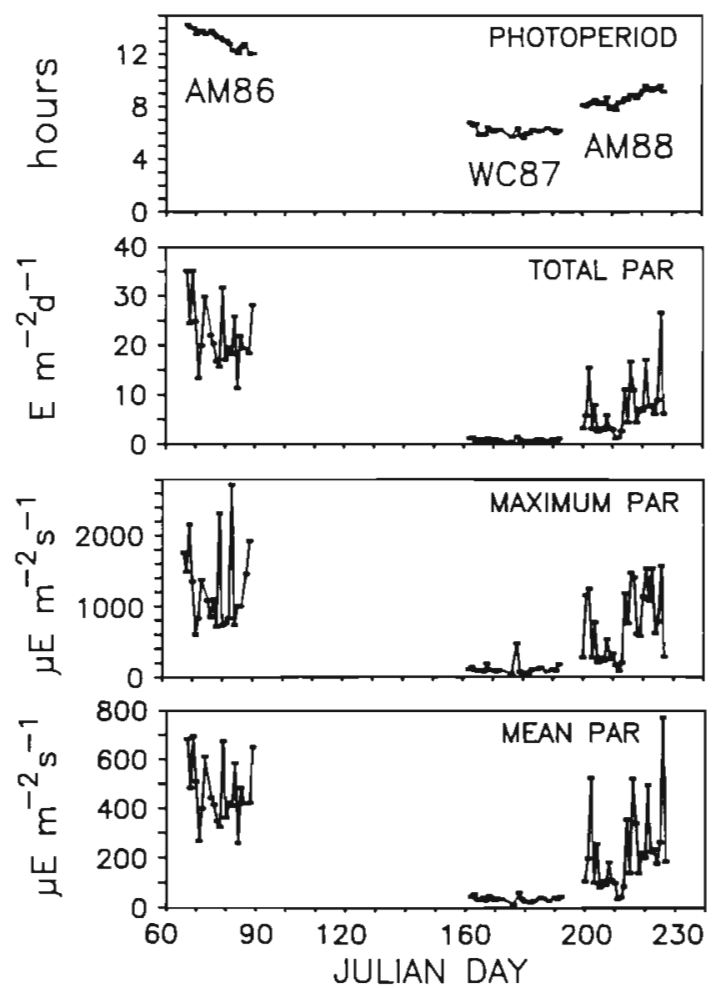

Fig. 3. Photoperiod and incident irradiance (PAR) measured during autumn and winter at the Weddell-Scotia Sea and west of the Antarctic Peninsula during AMERIEZ (AM) and WINCRUISE (WC) cruises from 1986 to 1988

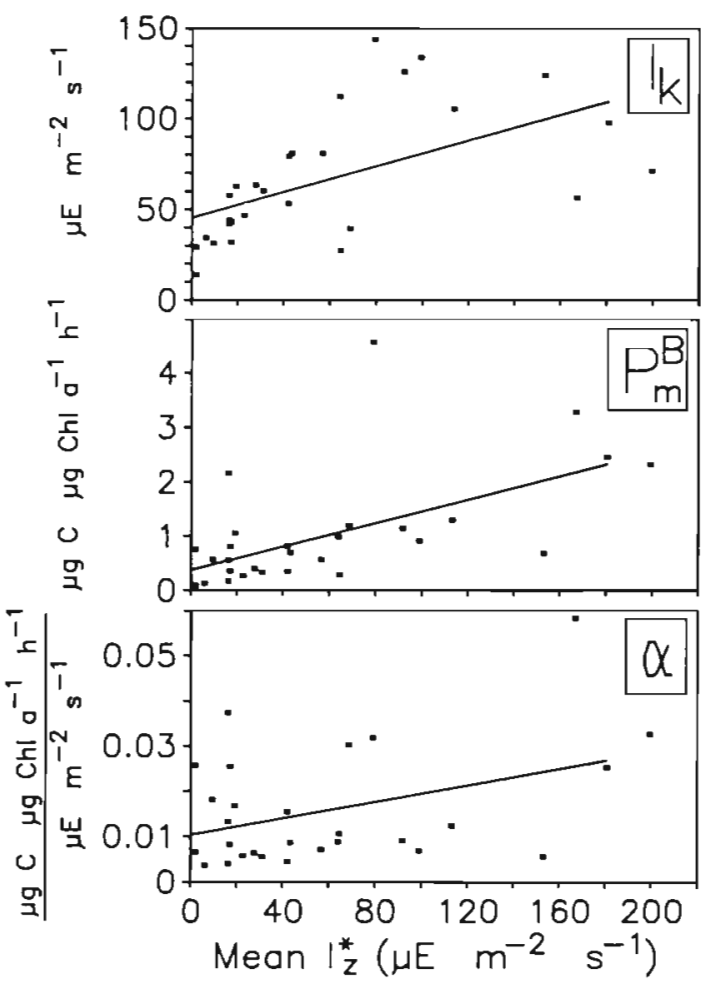

Fig. 4. Photosynthesis-irradiance characteristics of microalgae as a function of predicted in situ irradiance levels $\left(I_{z}^{*}\right.$ from mean PAR) in Antarctic pack ice. Lines represent the leastsquares linear regression

Table 3. Significance levels for linear regressions between photosynthesis-irradiance characteristics of microalgae and predicted irradiance levels in Antarctic pack ice. All slopes were positive and $p$ is the probability that the slope was not significantly different from $0 . I_{z}^{*}$ is incident irradiance corrected for ice depth and albedo (Eq. 4); maximum and mean values were based on maximum PAR $(n=29)$ and mean PAR $(n=28)$, respectively

\begin{tabular}{|cccl|}
\hline $\mathrm{X}$ & $\mathrm{Y}$ & $\mathrm{r}^{2}$ & $\mathrm{p}$ \\
\hline Maximum $I_{z}^{*}$ & $I_{k}$ & 0.600 & $<0.001$ \\
& $P_{\mathrm{m}}^{\mathrm{B}}$ & 0.260 & $<0.01$ \\
& $\alpha$ & 0.031 & $<0.4$ \\
Mean $I_{z}^{*}$ & $I_{k}$ & 0.318 & $<0.002$ \\
& $P_{\mathrm{m}}^{\mathrm{B}}$ & 0.333 & $<0.002$ \\
& $\alpha$ & 0.162 & $<0.04$ \\
\hline
\end{tabular}

substantial differences in photophysiological rates of microalgae in different irradiance fields within the pack ice. Both $P_{\mathrm{m}}^{\mathrm{B}}$ and $I_{k}$ were higher at higher irradiance levels and at shallower depths in vertical profiles. These trends in photosynthetic characteristics were more consistent with depth and irradiance than biomass; microalgae are found throughout the pack ice, with chl a maxima occurring at the surface, the 
bottom, or at intermediate locations (Table 2; Garrison et al. 1986, Kottmeier \& Sullivan 1990). Thus, the physiological state of pack ice microalgae appears to be related to in situ conditions rather than to any particular sequence of accumulation in ice microenvironments. We interpret these trends in physiological characteristics to indicate that during colonization and subsequent growth within the pack ice matrix, microalgae adapted to lower irradiance by decreasing photosynthetic capacity $\left(P_{\mathrm{m}}^{\mathrm{B}}\right)$ and $I_{k}$ as has been shown in temperate phytoplankton (Beardall \& Morris 1976, Falkowski 1981).

Because $P_{\mathrm{m}}^{\mathrm{B}}$ and $\alpha$ are normalized to $\mathrm{chl} \alpha_{\text {, lower rates }}$ could reflect higher cellular concentrations of $\mathrm{chl}$ a rather than lower phytosynthesis per cell. Changes in cellular chl a levels, if they occurred, would support our general interpretation that microalgae photoadapt within pack ice microenvironments because microalgae generally increase their cellular chl a content at lower irradiances (Falkowski 1981). However, changes in cellular chl a would not explain all the differences observed in photosynthetic characteristics: first, we did not observe trends in $\alpha$ equivalent to those in $P_{\mathrm{m}}^{\mathrm{B}}$ and second, $I_{k}$, which is the ratio $P_{\mathrm{m}}^{\mathrm{B}} / \alpha$ and is thus independent of cellular chlorophyll content, showed the best correlations with predicted irradiance. The same arguments can be used to dismiss the effects of chlorophyll associated with inactive or dead cells within the sea ice; the presence of inactive chlorophyll should diminish $P_{\mathrm{m}}^{\mathrm{B}}$ and $\alpha$ equally, but would not affect $I_{k}$. Thus, the evidence for photophysiological adaption by pack ice microalgae is substantial even when considering differences in cellular chlorophyll content or inaccuracies in estimating the concentration of chlorophyll associated with active cells.

P-I characteristics in pack ice microalgae were different to those published for fast ice microalgae, but similar to those previously reported for Antarctic phytoplankton. The distribution of $P_{\mathrm{m}}^{\mathrm{B}}$ values was similar to the distribution of light-saturated $P^{\mathrm{B}}$ values we have reported elsewhere (Lizotte \& Sullivan unpubl.); in that paper we summarized published $P_{\mathrm{m}}^{\mathrm{B}}$ values for Antarctic microalgae and found similar distributions for pack ice microalgae and phytoplankton, with fast ice microalgae distinguished by much lower values (typically $<0.5 \mu \mathrm{g} \mathrm{C} \mu \mathrm{g} \mathrm{chl} a^{-1} \mathrm{~h}^{-1}$ ). There do not appear to be any distinctions between Antarctic microalgae from pack ice, fast ice, and the plankton with regard to photosynthetic efficiency. The broad range 10.0036 to 0.058 ) and the mean (0.016) for $\alpha$ in pack ice microalgae was similar to the range and mean values reported for Antarctic phytoplankton (Marra \& Boardman 1984, Tilzer et al. 1985, 1986, SooHoo et al. 1987a, Brightmann \& Smith 1989) and for fast ice microalgae from McMurdo Sound (Palmisano et al. 1985, 1987, Rivkin et al. 1989). Burkholder \& Mandelli (1965) published the only previous P-I study on microalgae from Antarctic pack ice of which we have knowledge, reporting that microalgae from 2 surface ice populations had P-I relationships nearly identical to nearby phytoplankton populations. They also noted that surface ice microalgae had $P_{\mathrm{m}}^{\mathrm{B}}$ values and saturating light intensities ca 20 times higher than Bunt (1964) had reported for fast ice microalgae from McMurdo Sound.

Differences between microalgae from pack ice and those from fast ice may occur in most polar seas. Irwin (1990) observed similar P-I curves in microalgae from Arctic pack ice and in underlying phytoplankton, and made the observation that $P_{\mathrm{m}}^{\mathrm{B}}$ values were significantly higher than have been reported for Arctic fast ice microalgae. Relatively high $P_{\mathrm{m}}^{\mathrm{B}}$ values $>1 \mu \mathrm{g} \mathrm{C} \mu \mathrm{g}$ chl $a^{-1} \mathrm{~h}^{-1}$ ) have also been observed in microalgae from the pack ice of the Bering Sea (Robinson \& Sullivan unpubl.). Thus, we may be able to generalize for all polar seas that phytoplankton and pack ice microalgae have significantly higher photosynthetic capacities but similar photosynthetic efficiencies relative to fast ice microalgae.

Higher $P_{\mathrm{m}}^{\mathrm{B}}$ values often produce higher $I_{k}$ values in microalgae from pack ice and plankton relative to those from fast ice, suggesting the former are adapted to higher irradiances. $I_{k}$ values ranging from 30 to $150 \mu \mathrm{E}$ $\mathrm{m}^{-2} \mathrm{~s}^{-1}$ appear to be typical for pack ice microalgae (Irwin 1990, this study) and polar phytoplankton (Platt et al. 1982, 1987, Tilzer et al. 1985, 1986, SooHoo et al. 1987 a, Brightman \& Smith 1989), whereas fast ice algae typically have $I_{k}$ values less than $10 \mu \mathrm{E} \mathrm{m} \mathrm{m}^{-2} \mathrm{~s}^{-1}$ (Cota 1985, Palmisano et al. 1985,1987$). I_{k}$ is widely used as an indicator of photoadaptation. $I_{k}$ is highly correlated with under-ice irradiance $\left(\mathrm{r}^{2}=0.78\right)$ for microalgae inhabiting the bottom of fast ice in the Arctic (Gosselin et al. 1985, Demers et al. 1986), and in this study we showed that $I_{k}$ of pack ice microalgae was positively correlated with predicted irradiance levels. Therefore, higher $I_{k}$ values in pack ice microalgae suggest that they experience higher irradiances than the fast ice microalgae typically sampled from bottom ice and platelet ice microenvironments. Irwin (1990) makes a similar deduction based on a lack of photoinhibition in microalgae from Arctic pack ice. On average, pack ice microalgae experience higher irradiances than fast ice microalgae because often pack ice is thinner 10.01 to $1.5 \mathrm{~m}$ in our study) and active microalgae are found throughout, whereas microalgae from fast ice are typically concentrated at the bottom of a thicker $(>1.5 \mathrm{~m})$ ice column. Finally, as pointed out by Irwin $(1990)$, the dynamic nature of the pack ice can allow some incident irradiance to penetrate into the water column between floes and enter certain ice microenvironments from the sides and below, whereas fast ice typically presents a 
continuous ice sheet with downwelling irradiance entering only at the surface.

Primary production in the southern ocean is presumably dominated by phytoplankton, with sea ice microalgae making only a minor contribution to annual production ( $<1$ to $12 \%$; see Heywood \& Whitaker 1984 , Horner 1985a for reviews). However, the basis for previous estimates of photosynthetic production by sea ice microalgae has been the research conducted on fast ice populations. For example, phytoplankton beneath sea ice in McMurdo Sound can have a greater primary productivity than the overlying fast ice microalgae during the late winter and early spring, primarily due to the differences in biomass-specific photosynthetic rates (Rivkin et al. 1989). We found that microalgae from pack ice have higher photosynthetic capacities (indistinguishable from Antarctic phytoplankton) and inhabit microenvironments with higher irradiances, which suggests that pack ice microalgae could have much higher rates of primary production than previously estimated on the basis of evidence from fast ice regions. Any differences between the productivity of pack ice microalgae and the underlying phytoplankton would not be dependent on differences in photosynthetic ability, but on other factors such as the availability of light or nutrients. With respect to light, the contribution by pack ice microalgae to the total primary production of polar marine ecosystems would presumably be greatest during the late winter and spring when maximal sea ice coverage occurs. Extensive ice cover, low sun angle (higher reflectance), short photoperiod, low incident irradiance, and little stratification in the water column during winter are presumed to severely inhibit primary production by phytoplankton, and sea ice may be the most favorable habitat for algal production with respect to light availability. Consequently, our data suggest that pack ice microalgae may be the most important primary producers in polar marine ecosystems during the winter and early spring.

Acknowledgements. We thank K. Boettcher, K. R. Buck, W. S. Chamberlin, A. R. Close, D. L. Garrison, S. T. Kottmeier, D. Penny, and A. Spater for their assistance in the field. This work was supported by the National Science Foundation Division of Polar Programs grant DPP-84-44783 to C.W.S., and by the generous donation of ship time on WINCRUISE- 87 by L. Quetin.

\section{LITERATURE CITED}

Ackley, S. F., Buck, K. R., Taguchi, S. (1979). Standing crop of algae in the sea ice of the Weddell Sea region. Deep Sea Res. 26: 269-282

Ainley, D. G., Sullivan, C. W. (1989). AMERIEZ 1988: a summary of a winter cruise of the Weddell and Scotia Seas on Polar Duke. Antarctic J. U.S. 24: 144-147
Bates, S. S., Cota, G. F. (1986). Fluorescence induction and photosynthetic responses of Arctic ice algae to sample treatment and salinity. J. Phycol. 22: 421-429

Beardall, J., Morris, I. (1976). The concept of light intensity adaptation in marine phytoplankton: some experiments with Phaeodactylum tricornutum. Mar. Biol. 37: 377-387

Brightman, R. I., Smith, W. O. Jr (1989). Photosynthesisirradiance relationships of antarctic phytoplankton during austral winter. Mar. Ecol. Prog. Ser. 53: 143-151

Bunt, J. S. (1964). Primary productivity under sea ice in Antarctic waters. 2. Influence of light and other factors on photosynthetic activities of Antarctic marine microalgae. Antarct. Res. Ser. 1: 27-31

Burkholder, P. R., Mandelli, E. F. (1965). Productivity of microalgae in Antarctic sea ice. Science 149: 872-874

Clarke, D. B., Ackley, S. F. (1984). Sea ice structure and biological activity in the Antarctic marginal ice zone. J. geophys. Res. 89: 2087-2095

Cota, G. F. (1985). Photoadaptation of high Arctic ice algae. Nature, Lond. 315: 219-222

Demers, S., Legendre, L., Therriault, J. C., Ingram, R. G. (1986). Biological production at the ice-water ergocline. In: Nihoul, J. H. J. (ed.) Marine interfaces ecohydrodynamics. Elsevier, Amsterdam, p. 31-54

Falkowski, P. D. (1981). Light-shade adaptation and assimilation numbers. J. Plankton Res. 3: 203-216

Garrison, D. L., Ackley, S. F., Buck, K. R. (1983). A physical mechanism for establishing algal populations in frazil ice. Nature, Lond. 306: 363-365

Garrison, D. L., Buck, K. R. (1985). Sea-ice algal communities in the Weddell Sea: species composition in ice and plankton assemblages. In: Gray, J. S., Christiansen, M. E. (eds.) Marine biology of polar regions and effects of stress on marine organisms. John Wiley, New York, p. 103-122

Garrison, D. L., Buck, K. R., Fryxell, G. A. (1987). Algal assemblages in Antarctic pack ice and in ice-edge plankton. J. Phycol. 23: 564-572

Garrison, D. L., Sullivan, C. W., Ackley, S. F. (1986). Sea ice microbial communities in Antarctica. Bioscience 36 : 243-250

Gosselin, M., Legendre, L., Demers, S., Ingram, R. G. (1985). Responses of sea-ice microalgae to climatic and fortnightly tidal energy inputs (Manitounuk Sound, Hudson Bay). Can. J. Fish. Aquat. Sci. 42: 999-1006

Heywood, R. B., Whitaker, T. M. (1984). The Antarctic marine flora. In: Laws, R. M. (ed.) Antarctic ecology, Vol. 2. Academic Press, London, p. 373-419

Holm-Hansen, O., Lorenzen, C. J., Holmes, R. W., Strickland, J. D. H. (1965). Fluorometric determination of chlorophyll. J. Cons. int. Explor. Mer 30: 3-15

Horner, R. A. (1985a). Ecology of sea ice microalgae. In: Horner, R. A. (ed.) Sea ice biota. CRC Press, Boca Raton, p. 83-105

Homer, R. A. (1985b). Taxonomy of sea ice microalgae. In: Horner, R. A. (ed.) Sea ice biota. CRC Press, Boca Raton, p. $147-157$

Irwin, B. D. (1990). Primary production of ice algae on a seasonally-ice-covered, continental shelf. Polar Biol. 10 $247-254$

Jassby, A. T., Platt, T. (1976). Mathematical formulation of the relationship between photosynthesis and light for phytoplankton. Limnol. Oceanogr. 21: 540-547

Kottmeier, S. T., Sullivan, C. W. (1987). Late winter primary production and bacterial production in sea ice and seawater west of the Antarctic Peninsula. Mar. Ecol. Prog. Ser. 36: $287-298$

Kottmeier, S. T., Sullivan, C. W. (1990). Bacterial biomass and 
production in pack ice of Antarctic marginal ice edge zones. Deep Sea Res. 37: 1311-1330

Lewis, M. R., Smith, J. C. (1983). A small volume, short incubation time method for measurement of photosynthesis as a function of incident irradiance. Mar. Ecol. Prog. Ser. 13: 99-102

Marra, J., Boardman, D. C. (1984). Late winter chlorophyll a distributions in the Weddell Sea. Mar. Ecol. Prog. Ser. 19: $197-205$

Maykut, G. A. (1985). The ice environment. In: Homer, R. A. (ed.) Sea ice biota. CRC Press, Boca Raton, p. 21-82

Palmisano, A. C., SooHoo, J. B., Sullivan, C. W. (1985). Photosynthesis-irradiance relationships in sea ice microalgae from McMurdo Sound, Antarctica. J. Phycol. 21: 341-346

Palmisano, A. C., SooHoo, J. B., Sullivan, C. W. (1987). Effects of four environmental variables on photosynthesisirradiance relationships in Antarctic sea-ice microalgae. Mar. Biol. 94: 299-306

Palmisano, A. C., Sullivan, C. W. (1985). Growth, metabolism and dark survival in sea ice microalgae. In: Horner, R. A. (ed.) Sea ice biota. CRC Press, Boca Raton, p. 131-146

Platt, T., Harrison, W. G., Irwin, B., Hornc, E. D., Gallegos, C. L. (1982). Photosynthesis and photoadaptation of marine phytoplankton in the Arctic. Deep Sea Res. 29: 1159-1170

Platt, T., Harrison, W. G., Horne, E. P., Irwin, B. (1987). Carbon fixation and oxygen evolution by phytoplankton in the Canadian High Arctic. Polar Biol. 8: 103-113

Rivkin, R. B., Putt, M., Alexander, S. P., Merritt, D., Gaudet, L. (1989). Biomass and production in polar planktonic and sea ice microbial communities: a comparative study. Mar. Biol. 101: 273-283

Quetin, L. B., Ross, R. M. (1989). Summary of WINCRUISE II to

This article was presented by O. Holm-Hansen, La Jolla, California, USA the Antarctic Peninsula during June and July 1987 Antarctic J. U.S. 24: 149-151

Smith, W. O. Jr., (1987). Phytoplankton dynamics in marginal ice zones. Oceanogr. mar. Biol. A. Rev. 25: 11-38

SooHoo, J. B., Lizotte, M. P., Robinson, D. H., Sullivan, C. W. $(1987$ a). Photoadaptation of phytoplankton and light limitation of primary production in the ice-edge zone of the Weddell Sea. Antarctic J. U.S. 22: 185-187

SooHoo, J. B., Palmisano, A. C., Kottmeier, S. T., Lizotte, M. P., SooHoo, S. L., Sullivan, C. W. (1987b). Spectral light absorption and quantum yield of photosynthesis in sea ice microalgae and a bloom of Phaeocystis pouchetii from McMurdo Sound, Antarctica. Mar. Ecol. Prog. Ser. 116: $1-13$

Strickland, J. D. H., Parsons, T. R. (1972). A practical handbook of seawater analysis, 2nd edn. Bull. Fish. Res. Bd Can. 167: 1-311

Sullivan, C. W., Ainley, D. G. (1987). AMERIEZ 1986: A summary of activities on board the $\mathrm{R} \sim$ Melville and USCGC Glacier. Antarctic J. U.S. 22: 167-169

Tilzer, M. M., von Bodungen, B., Smetacek, V. (1985). Lightdependence of phytoplankton photosynthesis in the Antarctic Ocean: implications for regulating productivity. In: Siegfried, W. R., Condy, P. R., Laws, R. M. (eds.) Antarctic nutrient cycles and food webs. Springer-Verlag, Berlin p. 60-69

Tilzer, M. M., Elbrächter, M., Gieskes, W. W., Beese, B. (1986). Light-temperature interactions in the control of photosynthesis in Antarctic phytoplankton. Polar Biol. 5: 105-111

Weeks, W. F., Ackley, S. F. (1982). The growth, structure and properties of sea ice. U.S. Army Cold Regions Research and Engineering Laboratories. Monograph 82-1

Manuscript first received: August 12, 1990

Revised version accepted: January 10, 1991 